\title{
Kadın Doğum ve Çocuk Hastanesinde Doğum Yapan Kadınların Doğum Öncesi Bakım Alma Durumları
}

\section{Receiving Care Prior to Giving Birth for Women who Gave Birth at The Maternity and Chil- dren's Hospital}

\author{
Filiz TAŞ ${ }^{1}$, Merve GÜLPAK ${ }^{2}$, Ayșe Aslı OKTAY ${ }^{3}$, Nevres DEMİR ${ }^{4}$
}

\author{
${ }^{1}$ Dr. Öğr. Üyesi, Kahramanmaraş Sütçü İmam Üniversitesi, Sağlık Bilimleri Fakültesi Halk Sağlığı Hemşireliği, KAHRAMANMARAȘ \\ ${ }^{2}$ Öğr. Gör. , Kahramanmaraş Sütçü İmam Üniversitesi, Sağlık Bilimleri Fakültesi İç Hastalıkları Hemşireliği Anabilim Dalı, \\ KAHRAMANMARAŞ \\ ${ }^{3}$ Öğr. Gör. , Kahramanmaraş Sütçü İmam Üniversitesi, Sağlık Bilimleri Fakültesi Hemşirelik Esasları Anabilim Dalı, KAHRAMANMARAŞ \\ ${ }^{4}$ Hemşire, Kahramanmaraş Sütçü İmam Üniversitesi, Sağlık Bilimleri Fakültesi, KAHRAMANMARAŞ
}

\section{Öz}

Amaç: Bu çalışma kadınların doğum öncesi bakım ve eğitim hizmetlerinden yararlanma durumlarını değerlendirmek amacıyla yapılmıştır.

Gereç ve Yöntemler: Araştırmanın örneklemini Kahramanmaraş Kadın Doğum ve Çocuk Hastanesinde doğum yapan araştırmamıza katılmaya gönüllü 200 kadın oluşturmuștur. Veriler 28 sorudan oluşan anket formuyla toplanmış, SPSS programında yüzdelik ve Ki-Kare testleri ile değerlendirilmiştir. İstatistiksel anlamlılık düzeyi $\mathrm{p}<0.05$ olarak kabul edilmiştir.

Bulgular: Araştırmaya katılan kadınların yaş ortalaması 26.0 \pm 5.8 'tir. Gebelik döneminde kadınların \%56.5'inin doğum öncesi eğitim aldığı ve bu eğitimin \% 57.4'ünün doktorlar tarafından verildiği belirlenmiştir. Araştırmaya katılan kadınların \% 55.0’nın doğum öncesi kontrol sayısı 6 ve üzerindedir, \% 62.5'i her ay düzenli kontrole gitmiştir, \% 45.5’i kontrol için devlet hastanesini tercih etmiştir. Kadınlara bebeğin gelişimi, gebelik süresince bakım, beslenme, temizlik, doğum sonu kanama ve temizlik, doğumun nerede ve nasıl yapılacağı ve bebeğin emzirilmesi konularında bilgi verildiği saptanmıştır. Yapılan istatistiksel analizde kontrol için gidilen yerin uzaklığı ile kontrol sayısı, bebeğin doğum kilosu ile gebelik döneminde eğitim alma durumu ve doğum sonu bebeğin emzirilmesi hakkında eğitim alan kadınların bebeğin doğduktan sonraki emzirme süresi arasında ilişki bulunmuştur $(\mathrm{p}<0.05)$.

Sonuç: Çalışma sonunda kadınların doğum öncesi bakım hizmetlerinden standartlar ölçüsünde yararlandığ ve doğum öncesi bakım ve verilen eğitimlerin bebek sağlığını olumlu olarak etkilediği sonucuna ulaşılmıştır.

Anahtar Kelimeler: Gebelik, doğum öncesi bakım, eğitim hizmetleri

\section{Abstract}

Objective: This study has been carried out with the purpose of determining and evaluating how women benefit from care and education services prior to giving birth.

Material and Methods: The samples of the study consist of 200 women who have given birth at the Kahramanmaraş Maternity and Children's Hospital and volunteered to participate in our study. Data has been collected through the survey forms consisting of 28 questions and evaluated with the SPSS software program using the percentage and Chi-Square tests. The statistical significance level has been accepted as $\mathrm{p}<0.05$.

Results: The age average of women who participated in our study is $26.0 \pm 5.8$. It has been determined that $56.5 \%$ of the women have received education prior to giving birth and that $57.4 \%$ of this education has been given by doctors. $55.0 \%$ of the women who participated in the study have been examined for 6 times and more, $62.5 \%$ have had regular check-ups each month and $45.5 \%$ have preferred the state hospital for their examinations. It has been seen that the mothers were given information about the development of their babies, care, feeding, cleaning during pregnancy, periods and hygiene after giving birth, where and how the delivery would be and nursing their babies. In the statistical analysis, a relationship has been determined between the distance of the place the women were examined and the number of examinations, the babies' birth weight and the mothers' receiving education during their pregnancies and the duration of nursing their babies after giving birth for women who have received information about nursing babies $(\mathrm{p}<0.05)$.

Conclusion: As a result of the study, it has been concluded that the women have benefited from the care services at a standard level prior to giving birth and that the care and education given prior to giving birth have positively affected the health of the mothers and their babies.

Key Words: Care given prior to giving birth, educational services.

\section{GİRIŞ}

Ülkelerin gelişmişlik düzeylerini, çevre koşullarını ve toplumun sosyoekonomik düzeyini yansıtan en önemli göstergelerden biri ana-çocuk sağlığıdır. Toplumların ekonomik ve sosyal kalkınmasından söz edebilmek ve sağlıklı bir toplum oluşturabilmek için risk faktörlerinden

en çok etkilenen anne ve çocukların sağlık sorunlarının öncelikli olarak ele alınması ve iyileştirilmesi gerekir(1, 2).

Gebelik süresince kadının takibinin düzenli olarak yapılması, gerek ülkemizde gerek dünyada anne ve

\section{Bu çalışmanın özeti 18.Ulusal Halk Sağlığı Kongresinde Sözlü Olarak sunulmuştur. 05-09.Ekim 2015}

$\begin{array}{llll}\text { İletişim: } & \text { Filiz TAŞ, KSÜ Sağlık Bilimleri Fakültesi, Halk Sağlığı } & \text { Tel } & : 03443002610 \\ & \text { Hemşireliği, Kahramanmaraş } & \text { E-Posta }: \text { filiztas@ksu.edu.tr } \\ & & \text { Geliş Tarihi : } 25.11 .2018 \\ \text { DOI: } & \mathbf{1 0 . 1 7 5 1 7 / k s u t f d . 4 8 7 1 8 8} & \text { Kabul Tarihi : 24.12.2018 }\end{array}$


bebek ölümlerinin en aza indirilmesi için önem verilmesi gereken bir konudur. Kadının sağlığı, doğrudan kendisi için önemli olduğu kadar doğacak çocukların sağlığı açısından da önemlidir. Hem annenin, hem de doğacak bebeğin sağlığının korunması ve geliştirilmesinde doğum öncesi doğum ve doğum sonrası bakım hizmetlerinin nicelik ve nitelik olarak yeterli olması gerekmektedir. Sağlıklı yeni nesiller yetiștirebilmek öncelikle sağlıklı bir gebelik ve doğum süreci geçirmekle mümkündür. $\mathrm{Bu}$ nedenle kadının sağlığı, aile sağlığından ve dolaylı olarak toplum sağlığından ayrı düşünülemez (1-4).

Gelişmekte olan ülkelerde doğurganlık çağındaki kadınlar arasındaki en yaygın ölüm nedeni gebelik, doğum ve lohusalık sırasında meydana gelen komplikasyonlardır. Dünyada her yıl 528,000 anne ölümünün gerçekleştiği tahmin edilmektedir. Anne ölümlerinin seviyesi sağlik hizmetlerinin sağlanması ve kalitesi bakımından çok boyutlu bir kalkınma göstergesidir(4, 5). Sağlıklı bir gebelik geçirebilmek için doğum öncesi bakım önemlidir. Doğum öncesi bakım (DÖB) anne ve fetüsün tüm gebelik boyunca düzenli aralıklarla gerekli muayeneleri yapılarak ve önerilerde bulunarak, bir sağlık profesyoneli tarafından izlenmesidir (5-7). Bu izlemlerdeki amaç; kadınların sağlıklı bir gebelik geçirmelerini ve sağlıklı bebeklerin doğmasını sağlamaktır.

DÖB hizmetlerinin yeterliliği ile ilgili farklı kriterler ve farklı metodolojik yöntemler kullanılarak yapılan çalışmalarda doğum öncesi bakım hizmetlerinden yararlanma oranı \%25 ile \% 56.0 oranında değişmekte olduğu görülmektedir (6-9). Ülke genelinde iyi nitelikte DÖB hizmeti alma oranı \% 57.2 olarak belirlenmiştir(6, 8-11).

İlk gebelik ayından başlanılarak düzenli aralıklarla gebeliğin sonuna kadar sürdürülmesi, annenin ve fetüsün sağlık durumlarının değerlendirilmesi, doğum öncesi, doğum ve doğum sonrası, morbidite ve mortalitenin azaltılması için önemlidir $(5,8,12,13)$. Bu çalışma kadınların doğum öncesi bakım ve eğitim hizmetlerinden yararlanma durumlarını tespit etmek, doğum öncesi kontrollere gitme durumları ile aldıkları eğitimlerin anne ve bebek sağlığı açısından etkilerini incelemek amacıyla yapılmıştır.

\section{GEREÇ VE YÖNTEMLER}

\section{Araştırmanın Yapıldığı Yer ve Özellikleri}

Tanımlayıcı olarak yapılan bu çalışmanın verileri Kahramanmaraş Kadın Doğum ve Çocuk Hastanesinde toplanmıștır. Kahramanmaraş'ta bir tek kadın doğum ve çocuk hastanesi bulunmaktadır ve bu hastane sosyoekonomik durumu düşük- orta ve yüksek olan tüm kesimlerden annelerin doğum için tercih ettikleri bir hastanedir.

\section{Evren ve Örneklem}

Araştırmanın örneklemini Kahramanmaraş Kadın Doğum ve Çocuk Hastanesinde doğum yapan ve araştırmamıza katılmaya gönüllü 200 kadın oluşturmuştur. Örneklem seçimine gidilmemiş KasımAralık 2014 tarihlerinde doğum yaparak hastanede yatan araştırmamıza katılmak isteyen kadınlar alınmıştır. Araştırmaya katılma kriteri olarak kadının doğum yapması, hastanede yatıyor olması ve araştırmaya katılmak istemesi esas alınmıştır.

\section{Verilerin Toplanması}

Literatür bilgileri (1-5) doğrultusunda hazırlanan anket formlarında kadınların sosyo-demografik özelliklerine ilişkin 6, doğum öncesi bakım alma durumları ve doğum sonu kadınların ve bebeklerin özelliklerine yönelik 22 soru kadınlara yüz yüze görüşme yöntemi ile uygulanmıştır. Anket uygulamaları, hemşirelik bölümü üçüncü sınıf, ebelik bölümü dördüncü sinıf öğrencileri tarafından yapılmıştır.

\section{Araştırmanın Etik Yönü}

Araştırma için hastane yetkililerinden izin alınmış, doğumhane ve serviste çalışanlara bilgi verilmiştir. Görüşmeler yapilmadan önce annelerden sözel onay alınmıştır.

\section{Verilerin Değerlendirilmesi}

Veriler, SPSS 22.0 paket programında sayı, yüzdelik ve Ki-Kare testleri ile değerlendirilmiştir. İstatistiksel anlamlılık düzeyi $\mathrm{p}<0.05$ olarak kabul edilmiştir.

\section{BULGULAR}

Araştırmaya katılan kadınların yaş ortalaması 26.0 \pm 5.8 olarak tespit edilmiş olup, \% 8'inin 35 yaş üstü, \% 8 'inin 18 yaş ve altında olduğu belirlenmiştir. Kadınların $\% 58$ 'i ilköğretim mezunu olup \% 92'si ev hanımıdır ve \% 34ünün bir çocuğu vardır. Kadınların \% 88,4'ünün sağlık güvencesi bulunmakta olup, \% 61.5'inin aylık geliri 500$900 \mathrm{TL}$ arasındadır ve \% 72.5'i şehir merkezinde ikamet etmektedir. Çalışmamıza katılan kadınların \% 41.0'ının doğum aralığı 2-3 yıl, \% 50.8'inin doğumunu sezaryen doğum yöntemi ile gerçekleştiği ve geçirdikleri gebelik sayılarının birbirine yakın olduğu saptanmıştır. Gebelik döneminde kadınların \% 56.5'inin doğum öncesi eğitim aldığı ve bu eğitimin \% 57.4'ünün doktorlar tarafından verildiği belirlenmiştir. Kadınların doğum öncesi özellikleri Tablo 1'de verilmiştir.

Çalışmamıza katılan kadınların \% 55’inin doğum öncesi kontrol sayıs1 6 ve üzerinde iken. \% 62.5'i her ay düzenli kontrole gitmiştir. \% 45.5’i kontrol için devlet hastanesini tercih etmiştir ve kontrole giderken \% 58.5'ine eşlerinin eşlik etmiş olduğu belirlenmiştir. Kontroller sırasında kadınların \% 77.5’i gebeliği ile ilgili açıklayıcı bilgi verildiğini ifade etmiştir. Kontrol için gidilen yerin uzaklığ 1 sorusuna kadınların \% 63'ü bir saatten az cevabını vermiştir ve kadınların \% 59'u bu uzaklığın kontrol sayısını etkilemediğini belirtmiştir.

Tablo 2'de kadınların bebekleri ile ilgili özellikleri verilmiştir. Çalışmamıza katılan kadınların \% 75'inin bebeğinin beklenen tarihte doğduğu, \% 92.5'inin bebeğinin doğar doğmaz ağladığı, \% 91'inin bebeğinde herhangi bir sorun olmadığı. \%79.5'inin doğum kilosunun 2500-3500 gr arasinda olduğu, \% 68.5'inin bebeğini ilk bir saat içerisinde emzirdiği tespit edilmiştir.

Kadınların DÖE alma durumlarının analizi Tablo 3'de verilmiştir. Yapılan istatistiksel inceleme sonunda kontrol için gidilen yerin uzaklığı ile kontrol sayısının 
Tablo 1. Kadınların Doğum Öncesi Kontrolleri İle İlgili Özellikler (n=200)

\begin{tabular}{|c|c|c|c|}
\hline Kadınlar ile ilgili özellikler & Sayı & $\%$ & \\
\hline \multirow{4}{*}{ Doğum Öncesi Kontrol sayısı } & $3 \mathrm{Kez}$ & 31 & 15.5 \\
\hline & $4 \mathrm{Kez}$ & 24 & 12.0 \\
\hline & $5 \mathrm{Kez}$ & 35 & 17.5 \\
\hline & 6 ve Yukarısı & 110 & 55.0 \\
\hline \multirow{2}{*}{ Her Ay Düzenli Kontrol Durumu } & Evet & 125 & 62.5 \\
\hline & Hayır & 75 & 37.5 \\
\hline \multirow{4}{*}{ Kontrol İçin Tercih Edilen Sağlık Birimi } & Aile Hekimi & 68 & 34.0 \\
\hline & Özel Hastane & 34 & 17.0 \\
\hline & Tip Fakültesi & 7 & 3.5 \\
\hline & Devlet Hastanesi & 91 & 45.5 \\
\hline \multirow{4}{*}{ Kontrole Kiminle Gidildiği } & Eşi & 117 & 58.5 \\
\hline & Kayınvalide & 13 & 6.5 \\
\hline & Anne & 18 & 9.0 \\
\hline & Diğger & 52 & 26.0 \\
\hline \multirow{2}{*}{ Gebelikle İlgili Açılayıcı Bilgi Verilme durumu } & Evet & 155 & 77.5 \\
\hline & Hayır & 45 & 22.5 \\
\hline \multirow{3}{*}{ Kontrol İçin Gidilen Yerin Uzaklığ 1} & 1 Saatten $\mathrm{Az}$ & 126 & 63.0 \\
\hline & 1-2 Saat & 64 & 32.0 \\
\hline & 3-4 Saat & 10 & 5.0 \\
\hline \multirow{2}{*}{ Gidilen Yerin Uzaklığının Kontrol Sayını Etkileme durumu } & Evet & 82 & 41.0 \\
\hline & Hayır & 118 & 59.0 \\
\hline
\end{tabular}

Tablo 2. Kadınların Bebekleri İle İlgili Özellikler $(n=200)$

\begin{tabular}{|l|l|l|l|}
\hline $\begin{array}{l}\text { Bebekler ile ilgili } \\
\text { özellikler }\end{array}$ & & Sayı & $\%$ \\
\hline \multirow{3}{*}{$\begin{array}{l}\text { Bebeğin doğum } \\
\text { zamanı }\end{array}$} & Zamanında doğdu & 150 & 75.0 \\
\cline { 2 - 4 } & Erken doğdu & 34 & 17.0 \\
\cline { 2 - 4 } & Geç doğdu & 16 & 8.0 \\
\hline $\begin{array}{l}\text { Bebeğiniz doğar } \\
\text { doğmaz ağladı mı? }\end{array}$ & Evet & 185 & 92.5 \\
\cline { 2 - 4 } & Hayır & 15 & 7.5 \\
\hline $\begin{array}{l}\text { Bebeğinizde herhan- } \\
\text { gi bir sorun var mi? }\end{array}$ & Evet & 18 & 9.0 \\
\cline { 2 - 4 } & Hayır & 182 & 91.0 \\
\hline \multirow{3}{*}{$\begin{array}{l}\text { Bebeğin doğum } \\
\text { kilosu }\end{array}$} & 2500 gr'den az & 21 & 10.5 \\
\cline { 2 - 4 } & $2500-3500$ gr & 159 & 79.5 \\
\cline { 2 - 4 } & 3500 gr'den fazla & 20 & 10.0 \\
\hline \multirow{2}{*}{$\begin{array}{l}\text { Bebeğin doğduktan } \\
\text { ne kadar sonra } \\
\text { emzirildiği }\end{array}$} & İlk bir saat içerisinde & 137 & 68.5 \\
\cline { 2 - 4 } & 2 saat sonra & 37 & 18.5 \\
\cline { 2 - 4 } & Diğer & 26 & 13.0 \\
\hline
\end{tabular}

etkilenme durumu arasında anlamlılık bulunmuştur $(\mathrm{p}<0.05)$.

Bebeğin doğum kilosu ile gebelik döneminde doğum öncesi eğitim alma durumu arasında anlamlılık saptanmıştır $(\mathrm{p}<0.05)$. Gebelik sırasında doğum öncesi eğitim alan kadınların \% 48'inin bebek doğum kilosu 2500-3500 gr arasında bulunmuştur.

Gebelik döneminde doğum öncesi eğitim alan kadınların \%41.5'inin bebeği doğduktan sonra ilk bir saat içerisinde emzirdikleri saptanmıştır. Gebelik döneminde doğum öncesi eğitim alma durumu ile bebeği doğduktan sonra emzirme süresi arasında ilişki vardır. Doğum sonu bebeğin emzirilmesi hakkında eğitim alan kadınların bebeğin doğduktan sonraki emzirme süresi arasında anlamlılık bulunmuştur $(\mathrm{p}<0.05)$.

Bebeğin beklenen tarihte doğma durumu ile bebeğin doğum kilosu arasında anlamlı bir ilişki bulunmuş olup, bebeği beklenen tarihte doğanların \%63.0'nın doğum kilosu 2500-3500 kg arasında olduğu saptanmiştır $(\mathrm{p}<0.05)$.

Tablo 3. Kadınların Bazı Özelliklerine Göre DÖEAlma Dağılımlarının Analiz Sonuçları

Kadınlara hangi konularda eğitim verildiği Tablo 4'te görülmektedir. Kadınlara kontrol sirasında \% 65'ine bebeğin gelişimi, \% 45.5'ine gebelik süresince anne bakım, \% 23'üne doğum sonu bebek bakımı, \% 25'ine doğum sonu anne bakımı, \% 16.5'ine doğum sonrası aile planlaması, \% 65'ine gebelik sürecinde beslenme, $\%$ 28.5'ine gebelikte cinsel ilișki, \% 25'ine gebelikte temizlik, \% 23.5'ine doğum sonu kanama ve temizlik, \% 40.5'ine doğumun nasıl ve nerede olacağı ve \% 29'una doğum sonu bebeğin emzirilmesi konularında bilgi verildiği saptanmıştır. Kadınların \%5 7.4'ü kontrol sırasında verilen eğitimlerin doktorlar tarafından verildiğini ifade etmiştir.

\section{TARTIŞMA}

Dünya Sağlık Örgütü tarafından geliştirilen, anne ve çocuk sağlığında müdahale ve eylemleri yönlendiren ve rehberlik eden güvenli annelik paketinde; doğum öncesi bakım, anne ve yeni doğan ölümlerinin azaltılmasında temel müdahale olarak yer almaktadır $(5,14,15)$. 
Tablo 3. Kadınların Bazı Özelliklerine Göre DÖEAlma Dağılımlarının Analiz Sonuçları

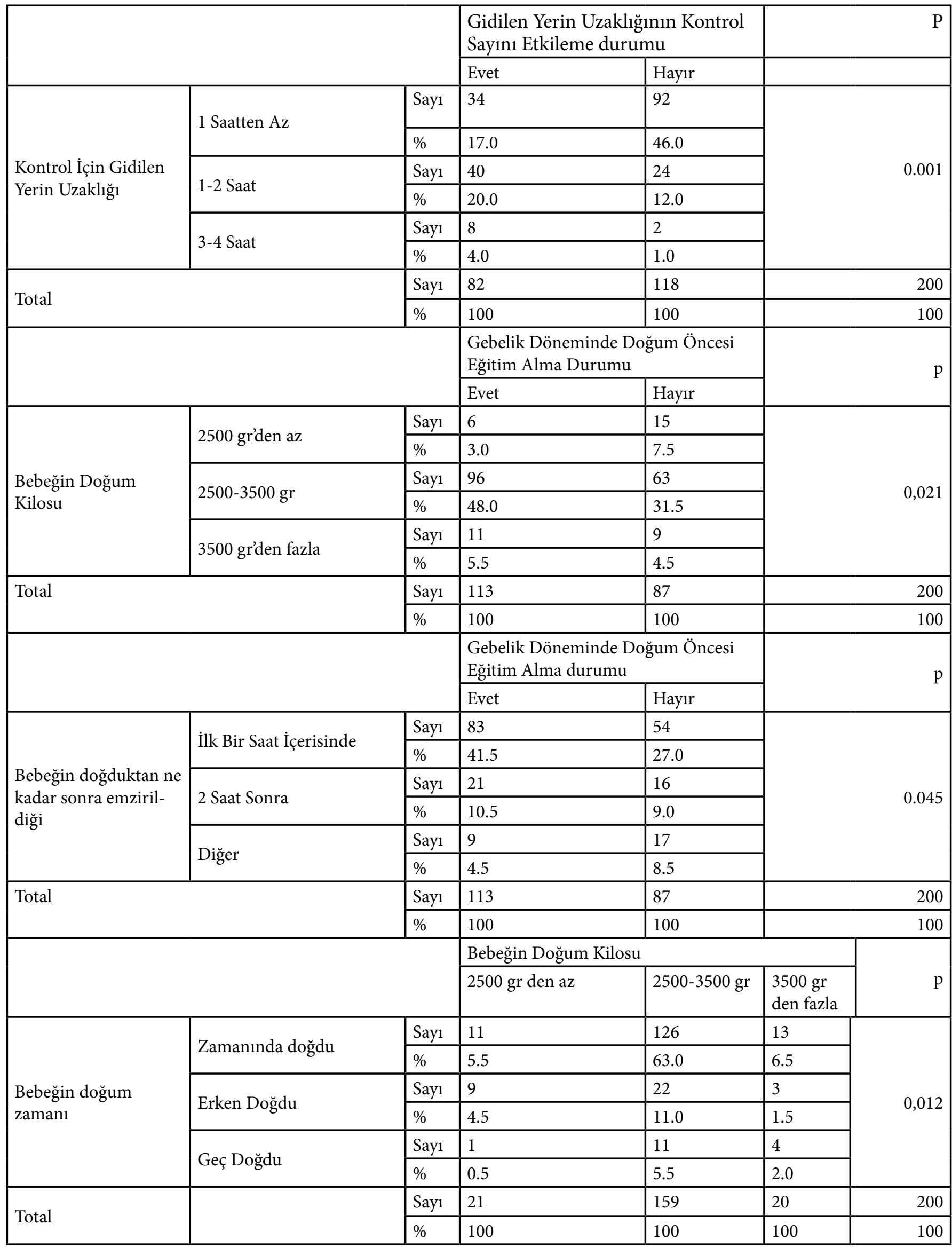

Yaptığımız çalışmada kadınların \%55.0’ının 6 ve üstü sayıda doğum öncesi kontrollere gittiği, belirlenmiştir (Tablo 1). Türkiye Nüfus ve Sağlık Araştırması 2013 (14), verilerine göre ülkemizde gebelerin \%89.0'1 4 ve üzerinde doğum öncesi bakım almıştır. Sağlık Bakanlığ her gebenin gebeliğin başlangicından itibaren en az 6 kez izlenmesini hedeflemektedir $(11,12,16)$. Kadınların yarısından fazlasının gebeliği döneminde kontrollere 
Tablo 4. Kadınlara Verilen Eğitim Konuları

\begin{tabular}{|c|c|c|c|}
\hline $\begin{array}{l}\text { Kontrol Sirasında Bilgi Verilen } \\
\text { Konular }\end{array}$ & Sayı & $\%$ & \\
\hline \multirow{2}{*}{ Bebeğin Gelişimi } & Hayır & 70 & 35.0 \\
\hline & Evet & 130 & 65.0 \\
\hline \multirow{2}{*}{$\begin{array}{l}\text { Gebelik Süresince Annenin } \\
\text { Bakımı }\end{array}$} & Hayır & 109 & 54.5 \\
\hline & Evet & 91 & 45.5 \\
\hline \multirow{2}{*}{ Doğum Sonu Bebek Bakımı } & Hayır & 154 & 77.0 \\
\hline & Evet & 46 & 23.0 \\
\hline \multirow{2}{*}{ Doğum Sonu Annenin Bakımı } & Hayır & 150 & 75.0 \\
\hline & Evet & 50 & 25.0 \\
\hline \multirow{2}{*}{$\begin{array}{l}\text { Doğum Sonunda Aile Planla- } \\
\text { ması }\end{array}$} & Hayır & 167 & 83.5 \\
\hline & Evet & 33 & 16.5 \\
\hline \multirow{2}{*}{$\begin{array}{l}\text { Gebelik Süresince Annenin } \\
\text { Beslenmesi }\end{array}$} & Hayır & 70 & 35.0 \\
\hline & Evet & 130 & 65.0 \\
\hline \multirow{2}{*}{ Gebelikte Cinsel İlişki } & Hayır & 143 & 71.5 \\
\hline & Evet & 57 & 28.5 \\
\hline \multirow{2}{*}{ Gebelikte Temizlik } & Hayır & 150 & 75.0 \\
\hline & Evet & 50 & 25.0 \\
\hline \multirow{2}{*}{$\begin{array}{l}\text { Doğum Sonu Kanama Ve } \\
\text { Temizlik }\end{array}$} & Hayır & 153 & 76.5 \\
\hline & Evet & 47 & 23.5 \\
\hline \multirow{2}{*}{$\begin{array}{l}\text { Doğumun Nasıl Ve Nerede } \\
\text { Olacağ1 }\end{array}$} & Hayır & 119 & 59.5 \\
\hline & Evet & 81 & 40.5 \\
\hline \multirow{2}{*}{$\begin{array}{l}\text { Doğum Sonu Bebeğin Emzi- } \\
\text { rilmesi }\end{array}$} & Hayır & 142 & 71.0 \\
\hline & Evet & 58 & 29.0 \\
\hline \multirow{4}{*}{$\begin{array}{l}\text { Konuların Kim Tarafından } \\
\text { Anlatıldığı }\end{array}$} & Doktor & 101 & 57.4 \\
\hline & Ebe & 66 & 37.5 \\
\hline & Hemşire & 6 & 3.4 \\
\hline & Diğer & 3 & 1.7 \\
\hline
\end{tabular}

•birden fazla seçenek ișaretlenmiștir.

gitmesi olumlu bir bulgudur ancak yeterli değildir. Hem annenin, hem de doğacak bebeğin sağlığının korunması ve geliştirilmesinde önemli olan doğum öncesi bakım, doğum ve doğum sonrası için temel koruyucu bir hizmettir. Bu hizmetlerden kadınların en üst düzeyde yararlanması gerekmektedir. Gebelerin doğum öncesi bakım almalarını ve bakım sıklıklarını etkileyen başlıca faktörler arasında; kadının öğrenim durumu, gelir getiren bir işte çalışması, ilk gebeliğinin olmaması, ailenin ekonomik durumu, daha önceki gebeliklerde annede veya bebekte sağlık sorunu bulunması gibi birçok faktörün önemli olduğu belirtilmektedir $(13,15$ 17). Çalışmamızda kadınların \%58.0'nın eğitim durumu ilköğretim seviyesinde olduğu \%92,0'ı ev hanımı olduğu ve $\% 61,5$ 'inin aylık gelirinin oldukça düșük olduğu tespit edilmiştir. Çalışmamızda istatistiksel inceleme sonunda kontrol için gidilen yerin uzaklığı ile kontrol sayısı arasında anlamlılık bulunmuştur (Tablo 3, p <0.05). Kadınların çoğunluğu kontrolleri için devlet hastanesi (\%45.5) ve aile hekimine (\%34.0) gittiğini belirtmiştir. Kadınların \%63.0’ı kontrol için gidilen yerin uzaklığının bir saatten az olduğunu belirtmiştir. Doğum öncesi bakım hizmetine ulaşmada yerleşim yeri önemli bir etkendir. Nitekim kentsel alanda yaşayan kadınlar kırsal alanda yaşayanlara göre daha fazla oranda doğum öncesi bakım almaktadır. Bunda ekonomik gücün etkisi kadar sosyokültürel özelliklerinde etken olduğu düşünülmektedir. Çalışmamıza katılan kadınların \%61.5'inin aylık geliri düşüktür ve kırsal bölgeden (\%27.5) geldiğini ifade eden kadınlar vardır. Çetin ve arkadaşlarının (2005), yaptığı çalışmada da kentsel alanda yaşayan kadınların doğum öncesi bakım alma oranı yüksek bulunmuştur (18).

Çalışmamız kapsamında kadınların bebekleri ile ilgili özelliklerine baktığımızda bebeklerin \%75.0'nın beklenen tarihte doğduğu, \%91.0'inda herhangi bir sorun olmadığ belirlenmiştir (Tablo 2). Bebeğin doğum kilosu ile gebelik döneminde doğum öncesi eğitim alma durumu arasında anlamlılık saptanmıştır (Tablo 3, $\mathrm{p}<0.05)$. Gebelik sırasında doğum öncesi eğitim alan kadınların \%48.0'ının bebeğinin doğum kilosu 2500$3500 \mathrm{gr}$ arasında bulunmuştur.

Çalışmamızda gebelik döneminde doğum öncesi eğitim alan kadınların \%41.5'inin bebeğini doğduktan sonra ilk bir saat içerisinde emzirdikleri saptanmıştır. Anne ve bebek arasındaki duygusal, fiziksel bağın kurulması, bebeğin anne sütünden maksimum seviyede yararlanması açısından bu önemli bir bulgudur. Doğum öncesi bakım alma, doğumu sağlık kuruluşunda gerçekleştirme, eğitimli sağlık personelinin doğuma katkısından dolayı bebek emzirme oranları yüksek bulunmuştur. Çalışmalar incelendiğinde normal doğum yapan annelerin yaklaşık \%50.0'ının ilk saatlerde bebeklerini emzirdikleri tespit edilmiştir $(19,20)$. Bebeğin emzirilmesinin önemi düşünüldügünde ülkemiz genelinde bu konuda daha çok eğitimlerin yapılması ve ilk saatlerdeki emzirmenin önemi üzerinde daha fazla durulması gerektiği düşünülmektedir.

İyi planlanan doğum öncesi bakım ve eğitim ile annenin olabilecek riskli durumlara karşı bilgilendirilmesi anne ve bebek sağlığı açısından önemlidir $(5,19,21,22)$. Nitekim maternal mortalite oranını arttıran risk faktörlerinden biri de prenatal bakım eksikliği ya da yokluğudur $(20,23,24)$. Hem annenin, hem de doğacak bebeğin sağlığının korunması ve geliştirilmesinde önemli olan doğum öncesinde, doğum sirasinda ve doğum sonrasında bakım temel koruyucu sağlık hizmetleri arasında yer almaktadır $(18,21)$.

Kadınlara verilen eğitim konuları açısından \%65.0'na gebelik sürecinde beslenme konusunda eğitim yapıldığı belirlenmiştir. Beslenme konusu ülkemizde özellikle anne ve bebek sağlığı açısından risk oluşturan en önemli konulardan birisidir. Yeterli ve dengeli beslenme konusunda annelere eğitim verilmesi hem doğum öncesi hem de doğum sonrası süreç için önemli bir bulgudur. Sözeri ve arkadaşlarının (2006), yaptıkları çalışmada kadınların \%56,8'inin beslenme ile ilgili bilgi aldıkları, \%12.2'sinin gebelikte bazı gıdaların azaltılması ve diyet yapılması gerektiğine inandığı belirtilmiştir (22). Gebelikteki yetersiz ve dengesiz beslenmenin uzun vadede toplum sağlığını da etkileyen olumsuz bir durum olduğu düşünüldüğünde bu konunun gebelikte anlatılmasının önemli olduğu vurgulanmalıdır (19-22). Yapılan çalışmalar incelendiğinde fetüsün intrauterin izlenmesi, annenin tetanosa karşı bağışıklanması, doğumun nerede, nasıl ve kim tarafından yapılacağ 1 , gebelikte beslenme, gebelikte hijyen, doğum, doğum sonu bakım, bebek 
bakımı ve doğum sonu kullanabileceği aile planlaması yöntemleri konusunda eğitimler verildiği görülmektedir $(16,18,21)$. Bu bulgular bizim çalışma bulgularımızla benzerlik göstermektedir. Bizim çalışmamızda da benzer konular gebe kadınlara anlatılmıştır (Tablo 4). Çalışmaya katılan kadınların \%57.4'ü eğitimlerin doktorlar tarafından verildiğini belirtmiştir. Konu ile ilgili literatür incelendiğinde gebelikte edinilen bilgilerin çoğunluğunun doktor tarafindan verildiği belirtilmiştir $(2,19,22)$. Bu sonuçlar bizim çalışmamızla benzerlik göstermektedir. Ayrıca yapılan çalışmalarda aile büyüklerinden, komşulardan veya arkadaşlardan gebelikle ilgili bilgilerin aldığı belirtilmektedir $(19,22)$. Gebelik ve lohusalık gibi hassas dönemlerde öğrenilen bilgilerin sağlıklı olması için bilirkişilerden alınması önemlidir. Bu nedenle çalışmamızda doktorlar tarafından edinilen bilgilerin değerli olduğu düşünülmektedir.

Sonuç olarak; doğum öncesi bakım ve takip anne ve yeni doğanın mortalite ve morbiditesinin önlenmesinde büyük öneme sahiptir. Çalışmamızda kadınların doğum öncesi kontrol ve bakım hizmetlerinden yararlanma durumları iyi düzeyde tespit edilmiștir. Doğum öncesi kontrollerde kadının düzenli olarak tartılması, kan basıncının takip edilmesi, kan tahlillerinin yapılması gibi takipler anne ve bebek sağlığı açısından önemlidir. Çalışmamızda bu bulgular sorgulanmamıștır. $\mathrm{Bu}$, çalışmamızın kısıtlılığı olarak kabul edilebilir. Yapılacak çalışmalarda doğum öncesi kontrollerde kadının düzenli şekilde takiplerinin yapılıp yapılmadığ 1 konusunda verilerin toplanması önerilebilir.

Doğum öncesi bakımın temel amacı, kadınların sağlıklı bir gebelik geçirmelerini, sağlıklı bebeklerin doğmasını sağlamaktır. Bu nedenle daha sağlıklı nesiller ve toplum için gebelik öncesi hizmetler konusunda kadınların bilgilendirilmesi ve bu hizmetlerden yararlanan kadınların sayısının artırılması önerilir. $\mathrm{Bu}$ durumda özellikle birinci basamakta çalışan sağlık personeli, doktor, ebe ve hemşirelere büyük rol ve sorumluluklar düşmektedir.

Anket uygulanmasında görev alarak araştırmanın yapılmasına katkı sağlayan Hemşirelik ve Ebelik Bölümü öğrencilerimize teşekkür ederiz.

\section{KAYNAKLAR}

1. Pasinlioğlu T. Healt education for pregnant women: the role of back ground characterstics. Patient Education and Counseling 2004; 53:101-106

2. Pirinççi E, Polat A, Kumru S, Köroğlu A. Bir üniversite hastanesinde doğum yapan kadınların doğum öncesi bakım alma durumu ve etkileyen faktörler. ADÜ Tip Fakültesi Dergisi 2010; 11: 1 - 7

3. Sevil Ü, Bakıcı A. Gebelikte yaşanan fiziksel sorunların saptanması ve bunları etkileyen etmenlerin incelenmesi. Sağlik ve Toplum Dergisi 2002;12: 56-62

4. Aydın DS, Yayla M.Türkiye Nüfus ve Sağlık Araştırması sonuçlarının antenatal bakım, fetal perinatal ve neonatal prognoz yönünden irdelenmesi. Perinatoloji Dergisi2010;18:

5. Al-Ateeq MA, Al-Rusaiess AA. Health education during antenatal care: the need for more. Journal of Women'sHealth 2015;7: 239-242
6. Hacettepe Üniversitesi Nüfus Etütleri Enstitüsü, ICON-INSTITUT Public Sector GmbH ve BNB Danışmanlık (2006) Ulusal Anne Ölümleri Çalışması, 2005. Sağlık Bakanlığ 1 Ana Çocuk Sağ lığı ve Aile Planlaması Genel Müdürlüğü ve Avrupa Komisyonu Türkiye Delegasyonu, Ankara.

7. Akış N, Pala K, Aydın N, Sarı H, Aytekin N,T. Bursa Nilüfer Halk Sağllğg Eğitim ve Araştırma Bölgesi’ndeki Gebelerde Risk Etmenlerinin Saptanması ve Doğum Öncesi Bakım Hizmetlerinin Değerlendirilmesi, Sağlık ve Toplum Dergisi2004; 14: 66-72.

8. Küçük E, Çan G, Topbaş M. Giresun I nolu Sağlık Ocağ 1 bölgesinde doğum yapan kadınların doğum öncesi, doğum ve doğum sonu bakım alma sıklı̆̆ı. IX. Halk Sağlığ 1 Kongresi. Kongre Kitapçığı 2004;232.

9. Kartal SB, Birler AG, Özkul D, Ünlüer S, Gürleyük S. Yamak A. ve ark. İstanbul'da Gebe, Lohusa, Bebek ve Çocuk İzlemlerinin İyileştirilmesi: GEBLİZ, TAF Prev Med Bull 2010; 9:289-296

10. Yanıkkerem E, Karadaş G, Adıgüzel B, Sevil U. 'Domestic Violence during Pregnancy in Turkey and Responsibility of Prenatal Healthcare Providers', American Journal of Perinatology2006;23: 93-103

11. Beyzadeoğlu H, Ekuklu G, Gül H. Edirne Muradiye sağlık ocağı bölgesinde Mayıs-Ağustos 2003 döneminde gebelik yaşayan kadınların doğum öncesi bakım almasını etkileyen etmenler. IX. Halk Sağlı̆̆ 1 Kongresi. Kongre Kitapçı̆̆ 2004;224

12. Akın A, Doğan BG, Enünlü T ve ark. Türkiye'de doğum öncesi bakım hizmetlerinden yararlanma. (Ed) Akın A. Türkiye’de Ana Sağlığı, Aile Planlaması Hizmetleri ve İsteyerek Düşükler, Türkiye Nüfus ve Sağlık Araştırması-1998 İleri Analiz Sonuçları. Hacettepe Üniversitesi Türkiye Aile Sağlığı ve Planlaması Vakfı UNFPA. Ankara. 2002; 212.

13. Ergin F, Aksu H, Demiröz H. Doğum öncesi ve doğum sonrası bakım hizmetlerinin nicelik ve niteliği. Anadolu Hemşirelik Ve Sağlık Bilimleri Dergisi2010;13: 1-9

14. Türkyılmaz S, Çavlin A. Türkiye Nüfus ve Sağlık Araştırması, Ulusal ToplantıTNSA-2013 Sonuçları, Hacettepe Üniversitesi, 2013https://docplayer.biz. tr/5969813-2013-turkiye-nufus-ve-saglik-arastirmasi.html.(Erişim Tarihi. 1.11.2018)

15. Ergöçmen BA, Tezcan S. Çağatay P. Üreme sağlı̆̆ı. In: Türkiye Nüfus ve Sağlık Araştırması 2008. Hacettepe Üniversitesi Nüfus Etütleri Enstitüsü, AÇSAP, DPT ve Avrupa Birliği, Ankara,2008: 143-54

16. Kılıç S, Uçar M, Temir P, Erten Ü, Sahin E, Karaca B, ve ark. Hamile kadınlarda doğum öncesi bakım alma sıklığ 1 ve bunu etkileyen faktörler. TSK Koruyucu Hekimlik Bülteni 2007; 6: 91-97

17. Yıldızoğlu I, Ökten S. Gebelerin DÖB hizmetlerinden yararlanma durumları. Hemşirelik Forumu Dergisi2001;4: 51-56

18. Çetin F, Güneş G, Karaoğlu L, Üstün Y. Turgut Özal Tip Merkezinde doğum yapan annelerin doğum öncesi bakım alma ve emzirmeye başlama durumları ve etkileyen faktörler. İnönü Üniversitesi Tip Fakültesi Dergisi 2005;12: 247-252 
19. Akyüz, Kaya T, Şenel N. Annenin Emzirme Davranışının ve Emzirmeyi Etkileyen Durumların Belirlenmesi. TSK Koruyucu Hekimlik Bülteni 2007; 6: 331-335

20. Yalınkaya A, Özcan Y, Kaya Z, Savas Z, Erdemoğlu M. Üniversite Hastanemizde maternal mortalite oran1. Perinatoloji Dergisi2008; 16: 9-13

21. Sönmez Y. Doğum öncesi bakım hizmetleri. Sürekli Tip Eğitimi Dergisi 2007;16: 9-12

22. Sözeri C, Cevahir R, Şahin S, Semiz O.Gebelerin gebelik süreci ile ilgili bilgi ve davranışları.Fırat Sağlık Hizmetleri Dergisi2006; 1: 92-103
23. Uzuner A, Ünalan P, Akman M, Çifçili S, Tuncer I, Çoban, E. ve ark. 'Providers' Knowledge of, Attitudetoandpractice of emergency contraception'. The European Journal of Contraception and Reproductive Health Care2005;10: 43-50

24. Beşer E, Ergin F, Sönmez A. Aydın ilmerkezinde doğum öncesi bakım hizmetleri. TSKKoruyucu Hekimlik Bülteni 2007;6:137-141 